\section{STAVOVI PREMA OSOBAMA S POTEŠKOĆAMA MENTALNOG ZDRAVLJA}

Prethodno priopćenje

Primljeno: rujan, 2020.

Prihvaćeno: ožujak, 2021.

UDK: $616.89: 31,6.647 .8$

DOI 10.3935/jsr.v28i1.391

Ana Petak ${ }^{1}$

orcid.org/0000-0001-5443-016X

Sveučilište u Zagrebu

Fakultet hrvatskih studija

Sanja Narić ${ }^{2}$

orcid.org/0000-0001-6302-1042

Neuropsihijatrijska bolnica Dr.

Ivan Barbot

Roberta Matković ${ }^{3}$ orcid.org/0000-0002-6967-4148

Nastavni zavod za javno zdravstvo, Služba za mentalno zdravlje

Ključne riječi:

mentalno zdravlje;

poteškoće mentalnog zdravlja; stavovi;

stigmatizacija

1 Ana Petak, mag. psihologije, e-mail: apetak@hrstud.hr

2 Sanja Narić, prof. socijalni pedagog, e-mail: sanja.naric@gmail.com

3 Roberta Matković, prof. sociologije, e-mail: robertamatkovic.rm@gmail.com 
iskustvo s traženjem podrške za mentalno zdravlje, no na dimenziji autoritarnosti značajan je interakcijski efekt informiranosti i traženja podrške. Rezultati ukazuju na važnost daljnjeg istraživanja odnosa stavova s traženjem podrške za mentalno zdravlje te razinom informiranosti o pitanjima zaštite mentalnog zdravlja.

\section{UVOD}

Problemi mentalnog zdravlja i njegove zaštite su među prioritetnim javnopolitičkim pitanjima u svijetu (Novak i Petek, 2018.). Istraživanja pokazuju kako je tijekom života više od $20 \%$ odrasle populacije zahvaćeno nekim od problema mentalnog zdravlja, a poremećaji nastali u ranoj dobi povezani su s onima u kasnijoj dobi. Troškovi vezani uz mentalne poremećaje iznose 3-4\% bruto nacionalnog dohotka zemalja (Štrkalj Ivezić i sur., 2008.), a neizravni troškovi zbog smanjene radne produktivnosti, narušene kvalitete života osobe s poteškoćom i cijele njezine obitelji te potencijalnog kroničnog tijeka nadilaze troškove zdravstvenog sustava (Cuijpers, Beekman i Reynolds, 2012.; Silobrčić Radić i Vrbanec, 2018.). Važnost promocije i prevencije mentalnog zdravlja početkom novog milenija prepoznaje Svjetska zdravstvena organizacija koja svojim smjernicama i izvješćima od 2001. godine nadalje utječe na sve svjetske politike, potičući vlade i neformalne organizacije na sudjelovanje u razvoju lokalnih strategija i prioriteta (World Health Organization, 2001.a, 2001.b, 2004., 2005., 20013.a, 2013.b). Europska komisija na konferenciji o mentalnom zdravlju 2008. godine pokreće Europski pakt za mentalno zdravlje i blagostanje koji izdvaja pet prioritetnih područja djelovanja u zaštiti mentalnog zdravlja, među kojima je i suprotstavljanje stigmi i socijalnoj isključenosti (European Commission, 2008.). Takav novi fokus promiče deinstitucionalizaciju i intervencije izvan tradicionalnih psihijatrijskih usluga, a ima za cilj integrirani i sveobuhvatni pristup, s tretmanom, promocijom i prevencijom kao jednako važnim komponentama. Takva transformacija postojeće prakse mentalnog zdravlja zahtijeva političko i profesionalno vodstvo te podršku putem međunarodne suradnje, no uspjeh ovog pristupa uvelike ovisi i o učinkovitoj društvenoj potpori osobama s mentalnim poteškoćama, osiguravanju jednakih prava u zajednici te o toleranciji i prihvaćanju u lokalnoj zajednici (Song i sur., 2005.). Nažalost, istraživanja pokazuju kako su stavovi zajednice prema osobama s poteškoćama mentalnog zdravlja još uvijek nepovoljni, što otežava implementaciju suvremenih tretmanskih pristupa (Igbinomwanhia, James i Omoaregba, 2013.; Reta i sur., 2016.; Sathyanath i sur., 2016.; Winkler i sur., 2016.; Shalaby, 2017.; Abi Doumit i sur., 2019.; Wolska i Malina, 2020.).

Stavovi su jedna od najvažnijih psiholoških dimenzija jer oblikuju percepciju ljudi o društvenom i fizičkom svijetu i direktno utječu na ponašanje (Albarracín i sur., 
2011.). Ajzen (2005.) ističe kako u nekim situacijama prema principu kompatibilnosti možemo predvidjeti pojedinačna ponašanja (usmjerena na određeni cilj) ukoliko poznajemo stavove pojedinca prema tim ponašanjima. Eagly i Chaiken (1993.) u svom $A B C$ modelu definiraju tri komponente stava - afektivnu, bihevioralnu i kognitivnu. Kako bi se stav manifestirao, mora biti predstavljen u pamćenju i dozvan pri susretu s objektom. Prema prirodi tog procesa, razlikuju se eksplicitni stavovi (svjesni, namjerni i kontrolirani koji podrazumijevaju kognitivni angažman, najčešće predmet istraživanja stavova) i implicitni stavovi (nesvjesni, spontani i automatski). Smatra se da implicitni stavovi proizlaze iz opetovanih iskustava i razvijaju se kroz procese socijalizacije (Devine, 1989.). Prema Greenwaldu i Banajiju (1995.), implicitni stavovi odražavaju introspektivno neidentificirane (ili netočno identificirane) tragove prošlih iskustava. Slijedom navedenoga, može se zaključiti kako u procesu socijalizacije možemo ciljano utjecati na formiranje stavova te, primjerice, edukacijom umanjiti i prevenirati razvoj stigmatizirajućih stavova.

U kontekstu mentalnih poteškoća, stigma se može definirati kao problem sa stavovima (predrasude), znanjem (neznanje) ili ponašanjem (diskriminacija) prema pojedincu s problemom mentalnog zdravlja, gdje diskriminacija predstavlja ponašajni odgovor koji proizlazi kao rezultat stigme (Rusch, Angermeyer i Corrigan., 2005.; Thornicroft i sur., 2007.). Stigma je jedan od najvažnijih faktora zbog kojih osobe odgađaju traženje pomoći vezano uz mentalno zdravlje te na različite negativne načine utječe na kvalitetu života osoba s poteškoćama mentalnog zdravlja (smanjena produktivnost na radnom mjestu, izostajanje s posla, izbjegavanje socijalnih kontakata) (Clement i sur., 2015.). Neki autori čak smatraju kako visoka razina stigmatizacije u društvu može jednim dijelom objasniti i kraći životni vijek osoba s mentalnim poremećajima (Hert i sur., 2011.; Nordentoft i sur., 2013.). Unatoč razlikama među pojedinim zemljama i nastojanjima da se kompletna skrb za mentalno zdravlje odvija u zajednici, visoko stigmatizirajući stavovi i dalje su prisutni gotovo svugdje u svijetu, kod svih društvenih struktura (Igbinomwanhia, James i Omoaregba, 2013.; Reta i sur., 2016.; Sathyanath i sur., 2016.; Winkler i sur., 2016.; Shalaby, 2017.; Abi Doumit i sur., 2019.; Wolska i Malina, 2020.). Istraživanja pokazuju kako su pojedinačne karakteristike kao što su dob, spol, etnička pripadnost i znanje o mentalnim bolestima povezane sa stavovima prema mentalnim poremećajima (Henderson i sur., 2016.). Najpozitivniji stavovi nalaze se kod osoba između 35 i 65 godina, žena, osoba bijele rase te onih koji imaju iskustvo poznavanja osobe s mentalnim poteškoćama (Ingram i sur., 2019.). Takva saznanja dobra su polazišna točka za planiranje i provođenje preventivnih aktivnosti, budući da je poželjno što detaljnije razotkriti fenomen koji se preventivnim aktivnostima želi umanjiti i otkloniti. Istraživanja pružaju smjernice kamo treba ulagati resurse i na koje načine se mogu realizirati ciljevi. Primjerice, ako utvrdimo da najnegativnije 
stavove prema mentalnim poteškoćama nalazimo među mlađom populacijom, te da edukacija smanjuje razinu stigmatizirajućih stavova, može se razmišljati o edukaciji mladih u sklopu redovnih školskih ili sveučilišnih kurikuluma ili čak putem društvenim mreža na kojima je takva populacija lako dostupna.

Crisp i sur. (2000.) istraživali su prevalentna vjerovanja u javnosti prema osobama s mentalnim poremećajem te su zaključili kako ona uključuju vjerovanje da su ljudi koji pate od mentalnih bolesti opasni, da te poteškoće stvaraju sami i da je s takvim pojedincima teško komunicirati. Aznar-Lou i sur. (2015.) navode kako je razina stigme i diskriminacije manja prema osobama koje pate od depresije i anksioznosti. Takvim vjerovanjima i ponašanjima djelomično pridonose i mediji nazivajući osobe s mentalnim poteškoćama nazivima poput »monstrum«, "psiho« i sl. (Simmons, Jones i Bradley, 2017.), što usmjerava pozornost na pitanje terminologije korištene za opis osoba s poteškoćama mentalnog zdravlja.

Svjetska zdravstvena organizacija definira mentalno zdravlje kao »stanje dobrobiti u kojem pojedinac ostvaruje svoje potencijale, može se nositi s normalnim životnim stresovima, može raditi produktivno i plodno te je sposoban(na) pridonositi svojoj zajednici« (WHO, 2001.c; str. 1). S druge strane, kod opisa poteškoća mentalnog zdravlja autori nisu suglasni. Diagnostic and statistical manual of mental disorders (5th ed.) (DSM-V) (American Psychiatric Association APA, 2013.: 20) koristi termine "duševni poremećaj« $i$ "psihički poremećaj« s definicijom predloženom kliničkoj, javnozdravstvenoj i istraživačkoj praksi koja opisuje »sindrom obilježen klinički značajnim smetnjama u kogniciji, regulaciji emocija ili ponašanju osobe koji su odraz disfunkcije psiholoških, bihevioralnih ili razvojnih procesa koji su u podlozi psihičkog funkcioniranja«. U literaturi se nailazi na nekonzistentnost u nazivlju osoba s poteškoćama mentalnog zdravlja, koje varira između termina mentalno, psihičko i duševno te prema intenzitetu, poput mentalne poteškoće (Dodig-Ćurković i sur., 2016.), mentalni poremećaj (Dodig-Ćurković i sur., 2016.), psihičke poteškoće (Sladović-Franz, 2019.; Vranko 2019.), psihički poremećaj (Gruber, 2012.; Dodig-Ćurković i sur., 2016.; Vranko, 2019.), psihički problemi (Eterović i sur., 2019.), duševne smetnje (Grozdanić, 2017.; Jukić, 2017.) ili duševna bolest (Szentmartoni, 1983.; Babić-Bosanac 2009.; Gruber, 2012.; Škugor i Sindik, 2017.). Prema Rječniku stranih riječi (Anić i Goldstein, 2002.), koristi se termin »mentalna bolest». Definicije mentalnog poremećaja mijenjale su se kroz drugu polovicu prethodnog stoljeća od definicija usmjerenih na stanje koje pogađa kogniciju, emocije i ponašanje prema holističkoj perspektivi koja stavlja fokus na zdravlje, umjesto na bolest. Promjene definicije prati i promjena fokusa sa stigme mentalnih poteškoća prema ulozi mentalnog zdravlja u sveukupnom zdravlju (Manderscheid i sur., 2010.). Nedosljednosti u terminologiji vjerojatno su odraz nastojanja usklađivanja nazivlja s novim smjernicama i promjenama fokusa prema mentalnom zdravlju (Manderscheid i sur., 2010.). U duhu smanjenja stigmatizacije is 
ciljem naglaska na zdravlje umjesto na bolest, u ovom radu je kao nazivlje za duševne poremećaje korištena terminologija »poteškoće mentalnog zdravlja«.

\section{CILJ I PROBLEMI}

Istraživanja koja ispituju stavove zajednice prema inkluziji i socijalizaciji osoba s mentalnim poteškoćama u Hrvatskoj su uglavnom usmjerena na specifične skupine, poput osoba s intelektualnim teškoćama (Rozman, 2007.) ili osoba s invaliditetom (Majsec-Sobota, Bakula-Anđelić i Šostar, 2006.), dok su istraživanja stavova prema osobama s poteškoćama mentalnog zdravlja slabo zastupljena. Cilj ovog istraživanja je opisati stavove ispitanika prema osobama s poteškoćama mentalnog zdravlja te ih usporediti s obzirom na neka sociodemografska obilježja i osobna iskustva.

Problemi:

1. Opisati dimenzije stavova prema osobama s poteškoćama mentalnog zdravlja.

2. Utvrditi povezanost stavova prema osobama s poteškoćama mentalnog zdravlja s dobi i subjektivnom procjenom informiranosti.

3. Usporediti stavove prema osobama s poteškoćama mentalnog zdravlja kod sudionika s obzirom na obrazovanje te iskustvo (osobno ili iskustvo bliskih osoba) traženja pomoći u ustanovama za zaštitu mentalnog zdravlja.

\section{METODOLOGIJA ISTRAŽIVANJA}

\section{Opis uzorka}

U istraživanju je sudjelovalo 108 sudionika (70,4\% ženskih, 25,9\% muških). Sudionici su u dobi od 21 do 59 godina ( $M=33,47, S D=7,240)$, s mjestom stanovanja u malom gradu (47,1\%), selu (34.,6\%) i velikom gradu (18,3\%). Prema obrazovnoj strukturi, $2 / 3$ sudionika je više ili visoke stručne spreme (64,5\%). Preostalu trećinu čine sudionici srednje stručne spreme $(21,5 \%)$ i sudionici s poslijediplomskim obrazovanjem (14\%). Osobno iskustvo traženja podrške za mentalno zdravlje ima $20,4 \%$ sudionika, dok $50 \%$ njih ima u okolini blisku osobu koja je za sebe potražila takvu pomoć.

\section{Instrumenti}

Skala stavova zajednice prema osobama s poteškoćama mentalnog zdravlja (Community Attitudes Toward The Mentally III - CAMI, Taylor i Dear, 1981.) korištena 
je kao mjera stavova. Za potrebe istraživanja skala je prevedena na hrvatski jezik od strane tri nezavisna prevoditelja čiji su prijevodi usuglašeni u konačnu verziju skale. Skala se sastoji od 40 čestica podijeljenih u 4 dimenzije - autoritarnost, benevolentnost, socijalno ograničavanje i stavovi/ideologija zajednice prema mentalnom zdravlju. Sudionici su procjenjivali svoje slaganje sa svakom od tvrdnji na Likertovoj skali od 5 stupnjeva ( 1 - Uopće se ne slažem, 5 - U potpunosti se slažem). Radi formiranja ukupnih rezultata neke su čestice rekodirane na način da viši ukupan rezultat pojedine subskale ukazuje na negativniji stav na toj dimenziji. Na početku primjene instrumenta nalazila se standardizirana uputa koja ukazuje na to da se termin »osoba s mentalnim poremećajem « u upitniku odnosi na odrasle osobe koje imaju dijagnozu iz područja mentalnih poteškoća, no sposobne su za samostalan život izvan bolnice. Pouzdanost skale dobivena u ovom istraživanju je visoka (Cronbach alfa $=0,902$ ), dok se pouzdanosti subskala kreću između 0,59 do 0,79. Svaka subskala obuhvaća 10 tvrdnji koje se odnose na određenu dimenziju. Subskala autoritarnost sažima stavove prema hospitalizaciji i skrbništvu kroz tvrdnje o potrebi hospitalizacije, tvrdnje o uzrocima mentalnih poteškoća (okrivljavanju bolesnika za poteškoće), razlike osoba s poteškoćama i bez poteškoća mentalnog zdravlja (osobe s poteškoćama kao manje vrijedne). Subskala benevolentnost opisuje društvenu odgovornost prema osobama s poteškoćama mentalnog zdravlja, suosjećanje, spremnost na osobni angažman te stav prema institucionalizaciji u smislu nepodržavanja grubih odluka i nadzora nad osobama s poteškoćama. Čestice subskale stavovi/ideologija zajednice prema mentalnom zdravlju prikazuju terapijsku vrijednost zajednice, utjecaj ustanova za zaštitu mentalnog zdravlja na susjedstvo te doživljaj opasnosti po lokalno stanovništvo, pri čemu osobe $s$ povoljnim stavom na dimenziji smatraju kako je oporavak osoba $s$ mentalnim poteškoćama moguć u njihovom neposrednom životnom okruženju, tj. u zajednici, sa što kraćim periodom institucionalizacije. Socijalno ograničavanje prikazuje doživljaj opasnosti od osoba s poteškoćama mentalnog zdravlja, spremnost na povjeravanje odgovornosti te održavanje socijalne distance, isključivanje i izoliranje osoba s poteškoćama iz zajednice, dislociranost ustanova za liječenje, izbjegavanje kontakta i odnosa s osobama s poteškoćama te doživljavanje osoba s poteškoćama kao teret za društvo.

Za potrebe istraživanja sastavljen je anketni upitnik namijenjen prikupljanju sociodemografskih podataka i ostalih informacija relevantnih za istraživanje (spol, dob, obrazovanje, mjesto stanovanja, iskustvo s ustanovama za zaštitu mentalnog zdravlja...). Pitanja o sociodemografskim podacima nalazila su se na kraju protokola. Veličina mjesta stanovanja sudionika ispitivana je česticom "Gdje ste proveli većinu svog života? « pri čemu su sudionici odgovarali odabirom jedne od ponuđenih opcija (veliki grad, mali grad, selo). Sudionici su procjenjivali svoju informiranost o mentalnom zdravlju odgovorom na česticu »Smatram se dovoljno 
informiranim/om o pitanju zaštite mentalnog zdravlja« (1 - Uopće se ne slažem, 5 - U potpunosti se slažem). Iskustvo s traženjem podrške za mentalno zdravlje ispitivano je česticama s dihotomnom odgovorom (da/ne): "Jeste li ikada Vi za sebe potražili podršku za mentalno zdravlje u javnoj ili privatnoj ustanovu/centru? « i »Je li ikada netko Vama blizak potražio podršku za mentalno zdravlje u javnoj ili privatnoj ustanovu/ centru? «

\section{Postupak}

Istraživanje je provedeno tijekom jeseni 2019. godine primjenom online upitnika, kao dio većeg istraživanja stavova prema mentalnom zdravlju i stavova prema poteškoćama mentalnog zdravlja. Primijenjeni protokol sastojao se od nekoliko psihologijskih instrumenata i anketnog upitnika sastavljenog za potrebe istraživanja. U radu je prikazan dio prikupljenih podataka koji nudi odgovore na istraživačke probleme, a detaljniji podaci o relevantnim instrumentima prikazani su u odlomku »Instrumentiu.

Elektroničkom poštom poslan je poziv standardiziranog sadržaja s poveznicom na upitnik te zamolbom za ispunjavanje i prosljeđivanje upitnika. Sudionici su punoljetne osobe iz opće populacije koje su se odazvale pozivu na istraživanje. Također, sudionici su bili upoznati kako je prikupljanje podataka dobrovoljno i anonimno te su u svakom trenutku mogli odustati od daljnjeg popunjavanja upitnika. Za ispunjavanje cijelog upitnika sudionicima bilo potrebno oko 15 minuta.

\section{REZULTATI I RASPRAVA}

Rezultati su analizirani u IBM SPSS Statistics 23 statističkom paketu.

Rezultati iz Tablice 1. prikazuju kako sudionici u prosjeku izražavaju najpovoljnije stavove na mjeri benevolentnosti ( $M=19,48, C=19, S D=5,692)$, a najnepovoljnije na mjeri stavova/ideologije zajednice prema osobama s poteškoćama mentalnog zdravlja ( $M=23,18, C=23, S D=5,496)$. Prosječni rezultati na subskalama pomaknuti su prema nižim vrijednostima teorijskog prosjeka skale, odnosno prema pozitivnijim stavovima. Ipak, rezultati unutar subskala znatno variraju, a prema njihovim opaženim rasponima ( $\min =11$, $\max =50)$, može se primijetiti kako su na razini pojedinih sudionika zastupljeni i izrazito povoljni i izrazito nepovoljni stavovi. Distribucije rezultata na dimenzijama autoritarnost i stavovi zajednice prema mentalnom zdravlju, prema Kolmogorov-Smirnovljevom testu, ne odstupaju od normalne distribucije, dok su distribucije rezultata dimenzija socijalno ograničavanje i benevolentnost pozitivno asimetrične. Kako je asimetričnost distribucija očekivana, a Levenovim testom utvr- 
đeno je kako su varijance svih skupina za usporedbu homogene, u daljnjoj su analizi korišteni parametrijski postupci obrade rezultata.

Tablica 1. Prikaz deskriptivnih podataka subskala CAMI

\begin{tabular}{|c|c|c|c|c|c|c|c|c|}
\hline & \multirow{2}{*}{$\begin{array}{l}\text { Min } \\
(10)\end{array}$} & \multirow{2}{*}{$\begin{array}{l}\text { Max } \\
(50)\end{array}$} & \multirow[t]{2}{*}{ M } & \multirow[t]{2}{*}{ SD } & \multirow[t]{2}{*}{ C } & \multicolumn{2}{|c|}{ K-S } & \multirow{2}{*}{$\begin{array}{c}\mathrm{z} \\
\text { (skew) }\end{array}$} \\
\hline & & & & & & $z$ & $p$ & \\
\hline Autoritarnost & 12 & 42 & 22,82 & 5,017 & 23 & 0,078 & 0,102 & 3,356 \\
\hline Benevolentnost & 11 & 50 & 19,48 & 5,692 & 19 & 0,144 & 0,000 & 8,305 \\
\hline $\begin{array}{l}\text { Socijalno } \\
\text { ograničavanje }\end{array}$ & 11 & 42 & 22,74 & 5,372 & 23 & 0,124 & 0,000 & 3,644 \\
\hline $\begin{array}{l}\text { Stavovi } \\
\text { zajednice }\end{array}$ & 10 & 46 & 23,18 & 5,496 & 23 & 0,083 & 0,065 & 2,803 \\
\hline
\end{tabular}

Rezultati su djelomično sukladni dosadašnjim istraživanjima. Istraživanja stavova prema osobama s poteškoćama mentalnog zdravlja u Hrvatskoj pokazuju da oni variraju od neprihvaćanja i stigmatizacije (Miletić i Sokolić, 2017.) do neutralnih i pozitivnih stavova (Kurtović i Svalina, 2016.; Škugor i Sindik, 2017.), te se preferira zadržavanje socijalne distance (Jokić-Begić, Kamenov i Lauri-Korajlija, 2005.). Dobiveni rezultati slični su onima iz istraživanja stavova javnosti prema osobama s poteškoćama mentalnog zdravlja provedenog u Bosni i Hercegovini 2012. gdje je utvrđeno kako opća populacija ima relativno dobronamjernije stavove, izražava toleranciju prema osobama s mentalnim poteškoćama i njihovoj rehabilitaciji u zajednici te iskazuje manju restrikciju prema mentalnim poteškoćama (Zavod za javno zdravstvo Federacije BiH, 2012.). Odnos pojedinih subskala CAMI s preostalim ispitivanim varijablama prikazan je u Tablici 2.

Tablica 2. Prikaz korelacija (Pearson $r$ ) dimenzija CAMI, dobi i samoprocjene informiranosti

\begin{tabular}{lccccc}
\hline & $\begin{array}{c}\text { Autori- } \\
\text { tarnost }\end{array}$ & $\begin{array}{c}\text { Bene- } \\
\text { volentnost }\end{array}$ & $\begin{array}{c}\text { Socijalno } \\
\text { ograničavanje }\end{array}$ & $\begin{array}{c}\text { Stavovi } \\
\text { zajednice }\end{array}$ & Dob \\
\hline $\begin{array}{l}\text { Benevolentnost } \\
\text { Socijalno } \\
\text { ograničavanje }\end{array}$ & $0,628^{* *}$ & 1 & & & \\
$\begin{array}{l}\text { Stavovi } \\
\text { zajednice }\end{array}$ & $0,627^{* *}$ & $0,678^{* *}$ & 1 & 1 & \\
$\begin{array}{l}\text { Dob } \\
\text { Samoprocjena }\end{array}$ & $0,593^{* *}$ & $0,597^{* *}$ & $0,668^{* *}$ & 0,045 & 1 \\
informiranosti & $-0,041$ & 0,178 & $0,202^{*}$ & $-0,127$ & $-0,020$ \\
\hline
\end{tabular}

$* * p<0,01, * p<0,05$ 
Interkorelacije rezultata na subskalama CAMI prikazane u Tablici 2. u skladu su s teorijskim očekivanjima (Taylor i Dear, 1981.).

Dob se pokazala povezana samo sa subskalom socijalno ograničavanje ( $r=$ $0,20)$, pri čemu viša dob ukazuje na viši rezultat, odnosno na negativniji stav starijih sudionika. Rezultat je u skladu s dosadašnjim istraživanjima prema kojima negativniji stav prema osobama s poteškoćama mentalnog zdravlja iskazuju starije osobe (Ilic i sur., 2014.; Hansson, Stjernswärd i Svensson, 2016.; Henderson i sur., 2016.). Žiropađa i Dulović (2014.) ističu kako su mlađe osobe sklonije uvažavanju ljudskih prava osoba s poteškoćama mentalnog zdravlja, manje sklone stigmatizaciji te češće iskazuju potrebu za blagonaklonim odnosom za razliku od starijih ispitanika koji više teže distanciranju od osoba s poteškoćama.

Dosadašnje istraživačke spoznaje upućuju na zaključak kako veća informiranost o mentalnom zdravlju vodi k pozitivnijim stavovima i nižoj stigmatizaciji osoba s poteškoćama (Song i sur., 2005.; Pejović-Milovancević i sur., 2009.; Vučić Peitl i sur., 2018.), što je djelomično u skladu s dobivenim rezultatima. Naime, samoprocjena informiranosti pokazala se značajno povezanom samo s dimenzijom autoritarnosti ( $r$ $=-0,24$ ) na način da viša samoprocjena informiranosti ukazuje na pozitivnije stavove na toj dimenziji (Tablica 2.), iako je ta korelacija niska.

Ostale dimenzije nisu se pokazale značajno povezane s dobi niti informiranosti, što nije očekivano. Potencijalno obrazloženje takvih rezultata je varijabla samoprocjene informiranosti o zaštiti mentalnog zdravlja. Moguće je pretpostaviti da su sudionici precijenili ili podcijenili svoju informiranost, zbog čega izostaje korelacija informiranosti s ostalim CAMI dimenzijama. Nadalje, moguće je da su stavovi više povezani s formalnim obrazovanjem nego sa samom informiranosti o poteškoćama mentalnog zdravlja. Hugo i sur. (2003.) su u istraživanju informiranosti o poteškoćama mentalnog zdravlja ispitanicima na čitanje dali osam vinjeta koje su prikazivale blaži ili teži oblik kliničke slike mentalnog poremećaja. Većinu prikazanih slučajeva ispitanici su objasnili povezanošću s povišenom razinom stresa ili nedostatkom snage volje, a ne u okviru medicinskog poremećaja, što sugerira da je samoprocjena znanja potencijalno upitna metoda procjene informiranosti o poteškoćama mentalnog zdravlja. Adekvatnim tretmanom sudionici su radije smatrali razgovor o problemu, nego traženje stručne pomoći, a psihoterapija je bila preferirana opcija liječenja posebno kod vinjeta sa suptilnom prezentacijom simptoma te zloupotrebom opojnih tvari. Ovaj rezultat svakako implicira kako bi se u budućim istraživačkim nastojanjima trebalo provjeriti količinu znanja te jasnije operacionalizirati informiranost ispitanika. 
Tablica 3. Prikaz ANOVA rezultata testiranja razlika u dimenzijama CAMI skale s obzirom na kategorije obrazovanja

\begin{tabular}{llllll}
\hline & & & & & F \\
& & N & M & SD & (2,104) \\
\hline \multirow{2}{*}{ Autoritarnost } & SSS & 23 & 25,35 & 4,376 & \\
& VSS & 69 & 21,71 & 4,710 & $5,390^{* *}$ \\
& Poslijediplomski & 15 & 24,00 & 6,036 & \\
\hline \multirow{3}{*}{ Benevolentnost } & SSS & 23 & 22,22 & 5,325 & \\
& VSS & 69 & 18,61 & 5,650 & $3,616^{*}$ \\
ograničavanje & Poslijediplomski & 15 & 19,27 & 5,650 & \\
\hline Stavovi zajednice & SSS & 23 & 24,35 & 5,356 & \\
& VSS & 69 & 22,04 & 5,315 & 1,814 \\
& Poslijediplomski & 15 & 23,60 & 5,539 & \\
\hline
\end{tabular}

${ }^{*} p<0,05 ; * p<0,01$

Rezultati ANOVA postupka (Tablica 3.) pokazuju značajne razlike u dimenzijama autoritarnosti i benevolentnosti s obzirom na obrazovanje sudionika. Dodatnom provedbom Scheffe post-hoc testa pokazalo se kako se razlikuju sudionici sa srednjom stručnom spremom (SSS) od sudionika s višom ili visokom stručnom spremom (VSS) na dimenzijama autoritarnosti (Mean Difference $=3,638$, std. Error $=1,166, p<0,05$ ) i benevolnetnosti (Mean Difference $=3,609$, std. Error $=1,344, p<0,05$ ), pri čemu sudionici sa SSS-om imaju negativnije stavove od sudionika s VSS-om. Općenito se smatra kako osobe s višim stupnjem obrazovanja imaju pozitivnije stavove prema osobama s mentalnim poteškoćama (Hansson, Stjernswärd i Svensson, 2016.; Winkler i sur., 2016.; Shalaby, 2017.), što su djelomično potvrdili i rezultati ovog istraživanja.

Osim stupnja formalnog obrazovanja, količina znanja o mentalnim bolestima utječe na pozitivnije stavove prema osobama s poteškoćama mentalnog zdravlja (Song i sur., 2005.). Antoniadis i sur. (2016.) zaključuju kako na stav studenata o mentalnim poteškoćama utječu demografski faktori, smjer na kojem studiraju i godina studija. Ženski spol, osobni kontakt s osobom s poteškoćom i sveučilišni studij (posebno društvene znanosti) povezani su s pozitivnijim stavovima. Asimopoulos i Martinaki (2018.) zaključuju kako među studentima socijalnog rada u Grčkoj pozitivnije stavove imaju 
oni na višim godinama studija i s većom razinom poznavanja mentalnih poremećaja. $\mathrm{U}$ istom su istraživanju s višom godinom studija povezani i niži rezultati na subskali autoritarnosti i socijalnog ograničavanja.

Vučić Peitl i sur. (2018.) ispitivali su stavove srednjoškolaca prema psihijatrijskim bolesnicima u tri različite srednje škole. Na temelju nalaza zaključili su kako učenici medicinske škole pokazuju pozitivnije stavove prema psihičkim bolesnicima, što upućuje na zaključak kako je formiranje stavova, osim s formalnim obrazovanjem, povezano i s dodatnim stručnim znanjem o psihijatrijskim poteškoćama. Pejović-Milovancević i sur. (2009.) proveli su edukaciju srednjoškolaca i prikazali rezultate istraživanja prije provođenja programa te nakon šest mjeseci. Program je sadržavao teorijsku podlogu i iskustvene radionice obrađujući sadržaje vezane za mentalno zdravlje. Nakon šest mjeseci uočeno je značajno snižavanje rezultata autoritarnosti i socijalnog ograničavanja te porast rezultata ideologije mentalne higijene, što ide u prilog ideji kako osim formalnog obrazovanja, edukacija o mentalnim poteškoćama smanjuje negativne stavove i stigmatizaciju osoba s poteškoćama.

S druge strane, Winkler i sur. (2016.) usporedili su stavove liječnika i opće populacije. Liječnici su imali manje stigmatizirajuće stavove, no u obje skupine je stigma i dalje prisutna. Najviše stigmatizirajući stavovi odnose se na doživljaj da su osobe s mentalnim poteškoćama opasne. Međutim, u odnosu na opću populaciju liječnici vide psihijatrijske bolnice kao suvremeniji pristup tretmanu osoba s mentalnim poteškoćama. Autori to objašnjavaju mogućnošću da liječnici imaju »na medicinu usmjeren« pogled na liječenje, zbog čega smatraju kako je medicinski tretman u bolnicama važniji od multidisciplinarne skrbi u zajednici. Takvi stavovi mogu negativno utjecati na provedbu reforme mentalnog zdravlja u zajednici. Može se, dakle, zaključiti kako formalna edukacija o mentalnim poremećajima sama po sebi ne vodi nužno pozitivnijim stavovima na svim subskalama.

Žiropađa i Dulović (2014.) nisu utvrdili očekivani utjecaj razine obrazovanja na iskazivanje općeg stava prema osobama s poteškoćama mentalnog zdravlja, što pripisuju suženom varijabilitetu razine obrazovanja sudionika. Prisutnost istovjetnog ograničenja uzorka također se mogla odraziti na rezultate ovog istraživanja.

Rezultati testiranja razlika u CAMI dimenzijama ovisno o veličini mjesta u kojem su sudionici proveli većinu života (veliki grad, mali grad, selo) nisu se pokazali značajnima (sve p vrijednosti provedenih ANOVA veće su od 0,05). Do sličnih rezultata dolaze i Ingram i sur. (2019.) istražujući utjecaj deprivacije malih sredina na stavove prema osobama s mentalnim poteškoćama. Nakon usporedbe individualnih karakteristika među ispitanicima na uzorku od 5820 stanovnika različitih sredina u Engleskoj, autori zaključuju kako na stavove značajnije utječe konceptualni, nego kontekstualni efekt. Nadalje, zaključuju kako su 90\% odraslih stanovnika Engleske aktivni korisnici interneta i socijalnih mreža, što može ukazivati na činjenicu da su individualni stavovi 
sve manje pod utjecajem geografske pripadnosti, a više podložni utjecaju socijalnih medija, foruma i grupa kojima pojedinci pripadaju u online kontekstu.

US National Institutes of Health (2007.) navodi kako je svaka četvrta osoba bila u doticaju s nekim oblikom mentalnog poremećaja, bilo da je obolio netko od bliskih članova obitelji ili oni sami. Ljudi koji žive s osobom s poteškoćama mentalnog zdravlja snose nerazmjerni teret poteškoće u usporedbi s osobama iz opće populacije (Kemp, Bates i Isaac, 2009.). Problemi mentalnih poremećaja prelijevaju se s osobe s poteškoćom na ostale članove obitelji i bliske prijatelje, narušavajući međusobne odnose, smanjujući kvalitetu života i ukupno blagostanje uključenih osoba. Utjecaj poteškoće mentalnog zdravlja bliskog člana obitelji na obiteljsku situaciju ovisi o vrsti mentalnog poremećaja na način da teže poteškoće mentalnog zdravlja, u smislu trajanja i općeg funkcioniranja osobe, ima veće negativne posljedice na obitelj (Koujalgi i Patil, 2013.).

Ipak, u ovom istraživanju utvrđeno je kako nema razlike u dimenzijama stavova s obzirom na iskustvo s traženjem podrške za mentalno zdravlje (osobno iskustvo traženja podrške za mentalno zdravlje i iskustvo traženja podrške za mentalno zdravlje neke od sudioniku bliskih osoba) (sve p vrijednosti provedenih t-testova veće su od 0,05).

Navedeni rezultat nije u skladu s očekivanjima prema kojima je iskustvo $s$ mentalnim poteškoćama značajan čimbenik pri formiranju stavova prema osobama s poteškoćama mentalnog zdravlja (Lyndon i sur., 2019.). U literaturi se poznavanje osoba s mentalnim poteškoćama ili vlastito iskustvo mentalnih poteškoća veže uz pozitivnije stavove, odnosno uz manju potrebu za socijalnom distancom (Angermeyer, Matschinger i Corrigan, 2004.) te veće suosjećanje i prosocijalne stavove (Angermeyer i Matschinger, 1996.). Lyndon i sur. (2019.) pokazuju kako poznavanje poteškoća mentalnog zdravlja predviđa manju potrebu za socijalnom distancom, no nije se pokazalo značajnim u predikciji stigme. Corrigan i sur. (2001.) ističu kako je efekt kontakta s osobom s poteškoćama mentalnog zdravlja bolji ukoliko osoba s kojom se uspostavlja kontakt umjereno odstupa od uobičajenih stereotipa. Nadalje, Žiropađa i Dulović (2014.) u svojim nalazima ističu kako su ispitanici koji su imali raniji kontakt s osobom s poteškoćama mentalnog zdravlja (naročito duži) izražavali pozitivniji stav prema osobama s poteškoćama mentalnog zdravlja i pozitivan odnos prema konceptu psihijatrije u zajednici. Bagić (2011.) je u ispitivanju stavova prema epilepsiji utvrdio kako su iskustva poznavanja osobe s epilepsijom i nazočnosti epileptičkom napadaju povezana s pozitivnijim stavovima i manjom socijalnom distancom te diskutira kako je općenito nepovoljan stav prema epilepsiji odraz općeg odnosa stigmatizacije navedene bolesti, a ne specifičnog odnosa prema ispitivanoj populaciji.

Iz svega navedenog, možemo pretpostaviti kako je direktan ili posredan kontakt s poteškoćama mentalnog zdravlja važan čimbenik formiranja stavova, čiji je učinak potrebno dublje i preciznije istražiti. 
Moguće obrazloženje odstupanja dobivenih rezultata od očekivanja je činjenica da nisu prikupljeni podatci o prirodi mentalnih poteškoća s kojima su sudionici bili u doticaju, o intenzitetu problema niti o vrsti odnosa s bliskom osobom. Unatoč tome, zbog visokog postotka ( $N=54 ; 50 \%$ ) sudionika koji su imali neki oblik takvog iskustva, iako ono nije precizno definirano, možemo zaključiti kako je važno osigurati institucionalnu mrežu podrške i pomoći kako bi se održavala dobrobit bliskih članova obitelji i prijatelja - kako zbog njih samih, tako i zbog zdravlja i oporavka osobe s poteškoćom.

Tablica 4. Prikaz ANOVA rezultata interakcije samoprocjene informiranosti i traženja podrške za mentalno zdravlje na rezultate na dimenziji autoritarnosti

\begin{tabular}{lcccc}
\hline ZV: autoritarnost & $\begin{array}{c}\text { Jeste li ikada Vi za sebe potražili podršku } \\
\text { za mentalno zdravlje u javnoj ili privatnoj } \\
\text { ustanovi/ centru? }\end{array}$ & $\mathbf{M}$ & $\mathbf{F ~ ( 1 , 9 8 )}$ \\
\hline Ne smatraju se & $\mathrm{Da}$ & 19,67 & \\
informiranima & $\mathrm{Ne}$ & 24,12 & \\
Smatraju se & $\mathrm{Da}$ & 23,38 & $5,209 *$ \\
informiranima & $\mathrm{Ne}$ & 22,18 & \\
\hline
\end{tabular}

${ }^{*} p<0,05$

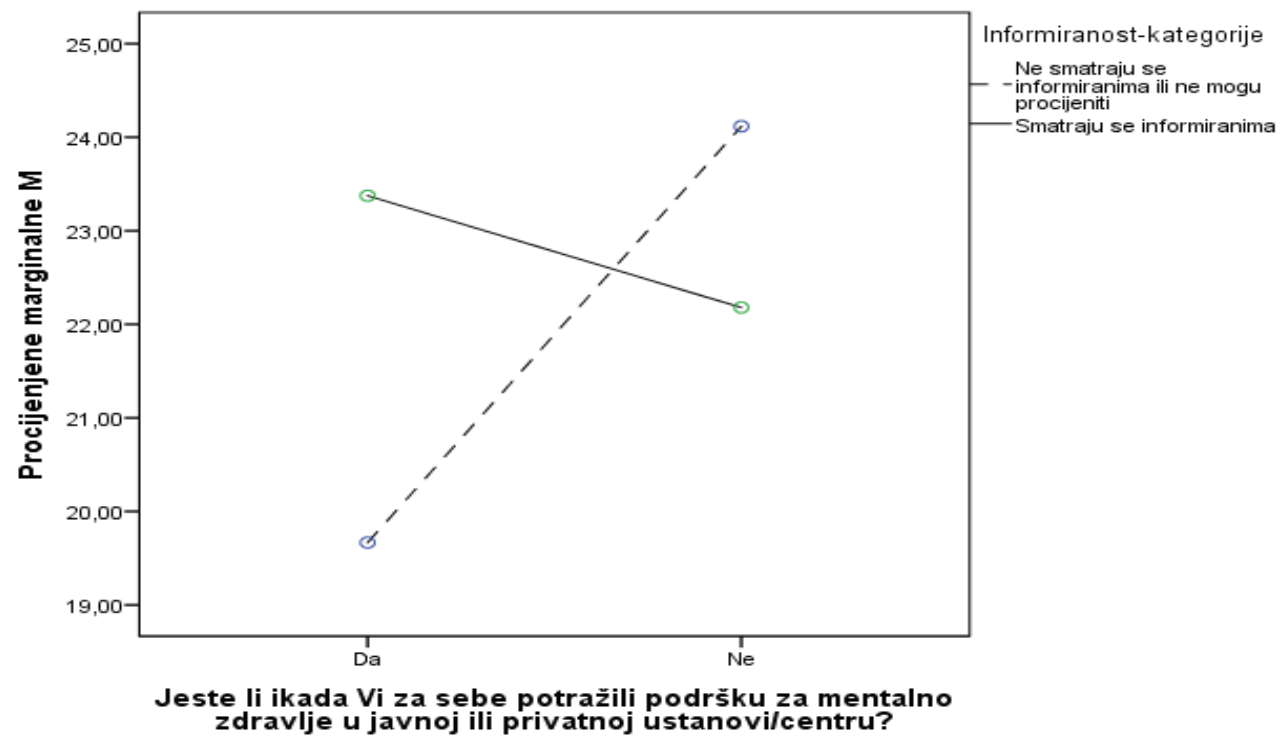

Slika 1. Prikaz rezultata interakcije samoprocjene informiranosti i traženja podrške za mentalno zdravlje na rezultate na dimenziji autoritarnosti 
lako nisu utvrđeni zasebni glavni efekti samoprocjene informiranosti i osobnog traženja podrške za mentalno zdravlje na rezultate CAMI dimenzija (za sve $p$ vrijednosti vrijedi $p>0,05$ ), rezultati prikazani u Tablici 4. i Slici 1. pokazuju značajan interakcijski efekt informiranosti i traženja podrške na dimenziji autoritarnosti $(\mathrm{p}<$ $0,05)$. U kategoriji sudionika koji se ne smatraju informiranima, traženje podrške za mentalno zdravlje vodi povoljnijim stavovima na autoritarnosti, dok u kategoriji sudionika koji se smatraju informiranima traženje podrške za mentalno zdravlje vodi nepovoljnijim stavovima na dimenziji autoritarnosti. Interakcijski efekt traženja podrške i samoprocjene informiranosti na preostalim dimenzijama CAMI skale nije se pokazao značajnim (sve $p>0,05$ ). Kako mediji često predstavljaju osobe s mentalnim poteškoćama u negativnom svjetlu (Wahl, Wood i Richards, 2002.; Angermeyer i sur., 2005.; Vukušić Rukavina, 2011.), moguće je da sudionici koji nemaju puno informacija o zaštiti mentalnog zdravlja zapravo nemaju niti informacije o funkcioniranju ustanova za zaštitu mentalnog zdravlja te ih percipiraju negativno sukladno negativnom predstavljanju u medijima. Kada se nađu u okolnostima u kojima trebaju potražiti podršku za vlastito mentalno zdravlje, čime su izloženi realnijem uvidu u funkcioniranje sustava za zaštitu mentalnog zdravlja u kojem i sami postaju dionici, njihovi stavovi postaju povoljniji. Nadalje, moguće je da sudionici koji se smatraju informiranima ujedno puno istražuju i proučavaju najidealnije pristupe zaštiti mentalnog zdravlja, pa zbog krnjeg sustava na koji naiđu u praksi imaju nepovoljnije stavove na dimenziji autoritarnosti od sudionika koji se smatraju informiranima, ali nisu bili u prilici tražiti podršku za vlastito mentalno zdravlje te usporediti realnost sustava sa svojim očekivanjima stvorenima na temelju dostupnih informacija. Takav nalaz ukazuje na važnost realnog prikaza funkcioniranja sustava zdravstvene zaštite u medijima, odnosno prikaza koji objektivno ističe i prednosti i nedostatke na koje građani mogu naići u traženju podrške za mentalno zdravlje.

\section{ZAKLJUČAK}

U zaključku možemo istaknuti kako sudionici imaju uglavnom blagonaklone stavove na svim dimenzijama skale. Viša samoprocjena informiranosti povezana je s povoljnijim stavovima na autoritarnosti, a mlađa dob s manjim socijalnim ograničavanjem. Sudionici sa SSS-om imaju negativnije stavove od sudionika s VSS-om samo na nekim dimenzijama stavova prema osobama s poteškoćama mentalnog zdravlja. Nema značajnih razlika u stavovima s obzirom na veličinu mjesta stanovanja i iskustvo s traženjem podrške za mentalno zdravlje. Ipak, rezultate nije moguće generalizirati na cjelokupnu populaciju, već ih je važno promatrati u kontekstu prigodnog uzorka sudionika prikupljenog online istraživanjem. Većina sudionika je ženskog spola, a istraživanja pokazuju kako žene 
imaju tolerantnije stavove (Žiropađa i Dulović, 2014.; Wolska i Malina, 2020.). Nadalje, većina sudionika je u dobnoj skupini između 25 i 44 godine, a ta se dob pokazala najtolerantnijom prema osobama s mentalnim poteškoćama (Hannigan, 1999.). Prema obrazovnoj strukturi, 2/3 sudionika je više ili visoke stručne spreme uz koju se također vežu pozitivniji stavovi prema poteškoćama mentalnog zdravlja (npr. Hansson i sur., 2016.). Pregled dobivenih rezultata implicira i potrebu da se u budućim istraživačkim nastojanjima provjeri količina znanja o mentalnim poteškoćama, operacionalizira informiranost ispitanika te prodube spoznaje o prirodi mentalnih poteškoća s kojima su ispitanici bili u doticaju te vrsta odnosa između ispitanika i osoba s poteškoćom mentalnog zdravlja. Konačno, zbog prirode online istraživanja uzorkom nije obuhvaćena populacija starijih sudionika koji se slabo ili nikako služe računalima.

Navedena obilježja uzorka imaju potencijal pomicati vrijednosti stavova prema pozitivnijem smjeru, što treba imati na umu kod tumačenja dobivenih rezultata. Unatoč nedostacima, rezultati predstavljaju značajan doprinos uvidu u stavove prema osobama s mentalnim poteškoćama, a poseban naglasak stavljaju na važnost obrazovanja i informiranosti u formiranju stavova. Kako bismo dobili jasniju sliku stavova koja nije zamagljena obilježjima uzorka, buduća istraživanja trebala bi koristiti veći i reprezentativan uzorak sudionika.

Thornicroft i sur. (2007.) objašnjavaju kako se stigma sastoji od poteškoća u znanju (neznanje i pogrešna informiranost), stavova temeljenih na predrasudama i diskriminativnom ponašanju. Prema tome, može se zaključiti kako informiranje šire javnosti o specifičnostima mentalnih poremećaja uvelike može pridonijeti stvaranju pozitivnijeg i produktivnijeg okruženja za ostvarenje globalnih ciljeva vezanih u promociju mentalnog zdravlja (Prince i sur., 2007.). Marketing i kampanje putem društvenih mreža i sličnih medija pokazali su se kao učinkovit način promocije mentalnog zdravlja među općom i ciljanom populacijom (Sampogna i sur., 2017.). Ključni aktivni sastojak takvih kampanja jest stvaranje kontakta između osoba sa i bez iskustva s mentalnim poremećajem (Thornicroft i sur., 2016.). U Hrvatskoj 82\% stanovništva ima pristup internetu, a 99\% u dobnoj skupini od 16 do 25 godina (Državni zavod za statistiku, 2019.), za koju se pokazalo da je populacija s izrazito negativnim stavovima i niskom razinom znanja o mentalnim poremećajima. Moderni načini komunikacije tako mogu postati medij za realizaciju važnih globalnih koraka u destigmatizaciji mentalnih poteškoća. Pri tome je i takve kampanje i programe neophodno pratiti znanstvenim istraživanjima.

Potreban je interdisciplinarni pristup na nekoliko razina koji obuhvaća društvo i pojedinca. Osim transformacije institucija, smanjenju stigme pridonijelo bi i uvođenje antidiskriminacijskih zakona i politika, bolja edukaciju pružatelja usluga skrbi, medijske kampanje, obuka novinara te općenito programi usmjereni na unapređivanje znanja i vještina u području mentalnog zdravlja. 


\section{LITERATURA}

1. Abi Doumit, C., Haddad, C., Sacre, H., Salameh, P., Akel, M., Obeid, S., Akiki, M., Mattar, E., Hilal, N., Hallit, S., \& Soufia, M. (2019). Knowledge, attitude and behaviors towards patients with mental illness: Results from a national Lebanese study. PloS one, 14(9), e0222172. https://doi.org/10.1371/journal.pone.0222172.

2. Ajzen, I. (2005). Attitudes, personality and behavior (2nd Edition). Berkshire: Open University Press.

3. Albarracín, D., Wang, W., Li, H. \& Noguchi, K. (2011). Structure of attitudes: Judgments, memory, and implications for change. In: Crano, W. D. \& Prislin, R. (eds.), Attitudes and attitude change. New York, London: Taylor and Francis, 19-40.

4. American Psychiatric Association (2013). Diagnostic and statistical manual of mental disorders (5th ed.). https://doi.org/10.1176/appi.books.9780890425596.

5. Angermeyer, M. C. \& Matschinger, H. (1996). The effect of violent attacks by schizophrenic persons on the attitude of the public towards the mentally ill. Social Science and Medicine, 43 (12), 1721-1728. https://doi.org/10.1016/S02779536(96)00065-2.

6. Angermeyer, M. C., Dietrich, S., Pott, D. \& Matschinger, H. (2005). Media consumption and desire for social distance towards people with schizophrenia. European Psychiatry, 20 (3), 246-250. https://doi.org/10.1016/j.eurpsy.2004.12.005.

7. Angermeyer, M. C., Matschinger, H. \& Corrigan, P. W. (2004). Familiarity with mental illness and social distance from people with schizophrenia and major depression: Testing a model using data from a representative population survey. Schizophrenia Research, 69 (2-3), 175-182. https://doi.org/10.1016/s09209964(03)00186-5.

8. Anić, V. \& Goldstein, I. (2002). Rječnik stranih riječi. Zagreb: Novi Liber.

9. Antoniadis, D., Gouti, A., Kaloudi, E., Tourlende, N., Douzenis, A., Christodoulou, C., Lykouras, L., Livaditis, M. \& Samakouri, M. (2016). Greek students' attitudes towards mental disorders. Psychiatriki, 27 (2).

10. Asimopoulos, C. \& Martinaki, S. (2018). An investigation into social work students' attitudes towards people with mental illness in Greece. International Journal of Culture and Mental Health, 11 (4), 741-752. https://doi.org/10.1080/ 17542863.2018.1561735.

11. Aznar-Lou, I., Serrano-Blanco, A., Fernández, A., Luciano, J. V. \& Rubio-Valera, M. (2015). Attitudes and intended behaviour to mental disorders and associated factors in catalan population, Spain: Cross-sectional population-based survey. BMC Public Health, 16 (1). https://doi.org/10.1186/s12889-016-2815-5. 
12. Babić-Bosanac, S. (2009). Zaštita prava na slobodu prisilno hospitaliziranih duševno oboljelih osoba pod okriljem članka 5. europske konvencije o zaštiti ljudskih prava i temeljnih sloboda. Pravni Vjesnik, 25 (1), 42-64.

13. Bagić, A. (2011). Uloga socio-demografskih i iskustvenih čimbenika u formiranju stavova i socijalne distance prema epilepsiji i oboljelima. Doktorska disertacija. Zagreb: Sveučilište u Zagrebu, Medicinski fakultet.

14. Clement, S., Schauman, O., Graham, T., Maggioni, F., Evans-Lacko, S., Bezborodovs, N. \& Thornicroft, G. (2015). What is the impact of mental health-related stigma on help-seeking? A systematic review of quantitative and qualitative studies. Psychology Medical, 45 (1), 11-27.

15. Corrigan, P. W., Edwards, A. B., Green, A., Diwan, S. L. \& Penn, D. L. (2001). Prejudice, social distance, and familiarity with mental illness. Schizophrenia Bulletin, 27 (2), 219-225. https://doi.org/10.1093/oxfordjournals.schbul.a006868.

16. Crisp, A. H., Gelder, M.G., Meltzer H. I. \& Rowlands, O. J. (2000). Stigmatisation of people with mental illness. The British Journal of Psychiatry, 177, 4-7. https:// doi.org/10.1192/bjp.177.1.4.

17. Cuijpers, P., Beekman, A. T. \& Reynolds, C. F. (2012). Preventing depression: A global priority. JAMA, 307 (10), 1033-1034. https://doi.org/10.1073/ pnas.1310766110.

18. Devine, P. G. (1989). Stereotypes and prejudice: Their automatic and controlled components. Journal of Personality and Social Psychology, 56, 5-18.

19. Dodig-Ćurković, K., Franić,T., Boričević Maršanić, V. \& Kovač, V. (2016). Mentalno zdravlje djece u Hrvatskoj - Treba li nam uopće dječja i adolescentna psihijatrija? U: Krželj, V. (ur.), Hrvatska proljetna pedijatrijska škola: XXXIII. seminar za liječnike i medicinske sestre. 143-150.

20. Državni zavod za statistiku (2019). Primjena informacijskih i komunikacijskih tehnologija (IKT) u kućanstvima i kod pojedinaca u 2019., prvi rezultati. Preuzeto s: https://www.dzs.hr/Hrv_Eng/publication/2019/02-03-02_01_2019.htm, (10.6.2020.)

21. Eagly, A. H. \& Chaiken, S. (1993). The psychology of attitudes. New York: Harcourt, Brace, \& Jovanovich College Publishers.

22. Eterović, I., Šiftar, I., Šuljok, M., Vukojević, N., Grgec-Petroci, V. \& Modrić Stanke, K. (2019). Stavovi stručnjaka prema posvojiteljskim obiteljima i potrebe za dodatnim edukacijama o posvojenju. U: Kokorić, S. B. (ur.), Posvojenje - različite perspektive, isti cilj. Zagreb: Na drugi način, 178-195.

23. European Commission (2008). European pact for mental health and well-being. EU high-level conference together for mental health and wellbeing. Brusseles: European Commission. 
24. Greenwald, A. G. \& Banaji, M. R. (1995). Implicit social cognition: Attitudes, self-esteem and stereotypes. Psychological Review, 102, 4-27.

25. Grozdanić, V. (2017). Bioetički senzibilitet zakona o zaštiti osoba s duševnim smetnjama. Zbornik Pravnog fakulteta Sveučilišta u Rijeci, 38 (3), 929-943. https:// doi.org/10.30925/zpfsr.38.3.1.

26. Gruber, E. N. (2012). Prijedlog intervencija u sustavu skrbi o mentalnom zdravlju a s ciljem inkluzije osoba s psihičkim poremećajima u društvo. Ljetopis socijalnog rada, 19 (1), 73-94.

27. Hannigan, B. (1999). Mental health care in the community: An analysis of contemporary public attitudes towards, and public representations of, mental illness. Journal of Mental Health, 8 (5), 431-440.

28. Hansson, L., Stjernswärd, S. \& Svensson, B. (2016). Changes in attitudes, intended behaviour, and mental health literacy in the Swedish population 2009-2014: An evaluation of a national antistigma programme. Acta Psychiatrica Scandinavica, 134, 71-79. https://doi.org/10.1111/acps.12609.

29. Henderson, C., Robinson, E., Evans-Lacko, S., Corker, E., Rebollo-Mesa, I., Rose, D. \& Thornicroft, G. (2016). Public knowledge, attitudes, social distance and reported contact regarding people with mental illness 2009-2015. Acta Psychiatrica Scandinavica, 134 (S446), 23-33. https://doi.org/10.1111/acps.12607.

30. Hert, M., Correll, C. U., Bobes, J., Cetkovich-Bakmas, M., Cohen, D., Asai, I., Detraux, J., Gautam, S., Moller, H. J. \& Ndetei, D. M. (2011). Physical illness in patients with severe mental disorders. Prevalence, impact of medications and disparities in health care. World Psychiatry, 10 (1), 52-77.

31. Hugo, C. J., Boshoff, D. E. L., Traut, A., Zungu-Dirwayi, N. \& Stein, D. J. (2003). Community attitudes toward and knowledge of mental illness in South Africa. Social Psychiatry and Psychiatric Epidemiology, 38 (12), 715-719. https://doi. org/10.1007/s00127-003-0695-3.

32. Igbinomwanhia, N., James, B. \& Omoaregba, J. (2013). The attitudes of clergy in Benin City, Nigeria towards persons with mental illness. African Journal of Psychiatry, 16 (3). https://doi.org/10.4314/ajpsy.v16i3.26.

33. Ilic, N., Henderson, H., Henderson, C., Evans-Lacko, S. \& Thornicroft, G. (2014). Chapter 3 attitudes towards mental illness HSE 2014. Preuzeto s: https://files. digital.nhs.uk/publicatio nimport/pub19 xxx/pub19295/hse20 14-ch3-mh-att. pdf (20.5.2020.)

34. Ingram, E., Jones, R., Schofield, P. \& Henderson, C. (2019). Small area deprivation and stigmatising attitudes towards mental illness: A multilevel analysis of Health Survey for England (2014) data. Social Psychiatry and Psychiatric Epidemiology. https://doi.org/10.1007/s00127-019-01722-w. 
35. Jokić-Begić, N., Kamenov, Ž. \& Lauri Korajlija, A. (2005). Kvalitativno i kvantitativno ispitivanje sadržaja stigme prema psihičkim bolesnicima. Socijalna psihijatrija, 33, 10-19.

36. Jukić, V. (2017). Dan prava osoba s duševnim smetnjama u Republici Hrvatskoj. Socijalna psihijatrija, 45 (4), 285-309.

37. Kemp, V., Bates, A. \& Isaac, M. (2009). Behavioural interventions to reduce the risk of physical illness in persons living with mental illness. Current Opinion in Psychiatry, 22 (2), 194-199. https://doi.org/10.1097/YCO.0b013e328325a585.

38. Koujalgi, S. R. \& Patil, S. R. (2013). Family burden in patient with schizophrenia and depressive disorder: A comparative study. Indian Journal of Psychological Medicine, 35 (3), 251-255. https://doi.org/10.4103/0253-7176.119475.

39. Kurtović, A. \& Svalina, N. (2016). Neke determinante stavova prema osobama s psihičkim poremećajima. Mostariensia, 20 (1-2), 21-39.

40. Lyndon, A., Crowe, A., Wuensch, K., McCammon, S. \& Davis, K. (2019). College students' stigmatization of people with mental illness: Familiarity, implicit person theory, and attribution. Journal of Mental Health, 28 (3), 255-259. https://doi. org/10.1080/09638237.2016.1244722.

41. Majsec-Sobota, V., Bakula-Anđelić, M. \& Šoštar, Z. (2006). Položaj osoba s invaliditetom u Gradu Zagrebu. Revija za socijalnu politiku, 13 (1), 53-65.

42. Manderscheid, R. W., Ryff, C. D., Freeman, E. J., McKnight-Eily, L. R., Dhingra, S. \& Strine, T. W. (2010). Evolving definitions of mental illness and wellness. Preventing chronic disease, 7 (1), A19.

43. Miletić, L. \& Sokolić, F. (2017). Stigmatizacija osoba s duševnim smetnjama - Istraživanje stajališta studenata pravnog fakulteta u Rijeci. Zbornik Pravnog fakulteta Sveučilišta u Rijeci, 38 (3), 1163-1186. https://doi.org/10.30925/zpfsr.38.3.9.

44. Nordentoft, M., Wahlbeck, K., Hallgren, J., Westman, J., Osby, U., Alinaghizadeh, H., Gissler, M. \& Laursen, T. M. (2013). Excess mortality, causes of death and life expectancy in 270,770 patients with recent onset of mental disorders in Denmark, Finland and Sweden. PLoS One, 8 (1), e55176. https://doi.org/10.1371/ journal.pone.0055176.

45. Novak, M. \& Petek, A. (2018). Ekspertiza i razvoj hrvatske politike mentalnog zdravlja: percepcija stručnjaka iz područja mentalnog zdravlja. Socijalna psihijatrija, 46 (4), 343-371.

46. Pejović-Milovancević, Lecić-Tosevski, D., Tenjović, L., Popović-Deusić, S. \& Draganić-Gajić, S. (2009). Changing attitudes of high school students towards peers with mental health problems. Psychiatria Danubina, 21 (2), 213-219.

47. Petz B. (ur.) (1992). Psihologijski rječnik. Zagreb: Prosvjeta.

48. Prince, M., Patel, V., Saxena, S., Maj, M., Maselko, J., Phillips, M. R. \& Rahman, A. (2007). No health without mental health. Lancet, 370 (9590), 859-877. 
49. Reta, Y., Tesfaye, M., Girma, E., Dehning, S. \& Adorjan, K. (2016). Public stigma against people with mental illness in Jimma Town, Southwest Ethiopia. PLOS ONE, 11 (11), e0163103. https://doi.org/10.1371/journal.pone.0163103.

50. Rozman, B. (2007). Utjecaj u zajednici utemeljene rehabilitacije na kompetentnost deinstitucionaliziranih osoba s intelektualnim teškoćama. Hrvatska revija za rehabilitacijska istraživanja, 43 (2), 67-81.

51. Rusch, N., Angermeyer, M. C. \& Corrigan, P. W. (2005). Mental illness stigma: Concepts, consequences, and initiatives to reduce stigma. European Psychiatry, 20 (8), 529-539. https://doi.org/10.1016/j.eurpsy.2005.04.004.

52. Sampogna, G., Bakolis, I., Evans-Lacko, S., Robinson, E., Thornicroft, G. \& Henderson, C. (2017). The impact of social marketing campaigns on reducing mental health stigma: Results from the 2009-2014 Time to Change programme. European Psychiatry, 40, 116-122. https://doi.org/10.1016/j.eurpsy.2016.08.008.

53. Sathyanath, S., Mendonsa, R. D., Thattil, A. M., Chandran, V. M. \& Karkal, R. S. (2016). Socially restrictive attitudes towards people with mental illness among the non-psychiatry medical professionals in a university teaching hospital in South India. International Journal of Social Psychiatry, 62 (3), 221-226. https:// doi.org/10.1177/0020764015623971.

54. Shalaby, A. S. (2017). Attitude of a sample of Egyptian community pharmacists and their assistants toward psychiatric patients. Middle East Current Psychiatry, 24 (2), 79-84. https://doi.org/10.1097/01.xme.0000513073.77707.e2.

55. Silobrčić Radić, M. \& Vrbanec, I. (2018). Mentalni poremećaji u Republici Hrvatskoj. Zagreb: Hrvatski zavod za javno zdravstvo.

56. Simmons, L., Jones, T. \& Bradley, E. (2017). EJMH reducing mental health stigma: The relationship between knowledge and attitude change. European Journal of Mental Health, 12 (1), 25-40. https://doi.org/10.5708/EJMH.12.2017.1.2.

57. Sladović Franz, B. (2019). Procjena i uparivanje posvojitelja i djeteta. U: Kokorić, S. B. (ur.), Posvojenje - različite perspektive, isti cilj. Zagreb: Na drugi način, 3861.

58. Song, L. Y., Chang, L.Y., Shih, C.Y., Lin, C.Y. \& Yang, M .J. (2005). Community attitudes towards the mentally ill: The results of a national survey of the Taiwanese population. The International Journal of Social Psychiatry, 51 (2), 162-176. https:// doi.org/10.1177/0020764005056765.

59. Szentmartoni, M. (1983). Religioznost i duševno zdravlje. Obnovljeni Život, 38 (2), 113-125.

60. Škugor, T. \& Sindik, J. (2017). Stavovi prema duševnim bolesnicima u društvu - Usporedba u odnosu na odabrane socio-demografske čimbenike. Sestrinski glasnik, 22 (3), 273-279. https://doi.org/10.11608/sgnj.2017.22.053. 
61. Štrkalj Ivezić, S., Jukić, V., Štimac Grbić, D., Ćelić, I., Brečić, P., Silobrčić Radić, M., Bagarić, A. \& Ćurković, M. (2008). Organizacija liječenja oboljelih od mentalnih poremećaja u Republici Hrvatskoj. Acta Medica Croatica, 72, 179-188.

62. Taylor, S. M. \& Dear, M. J. (1981). Scaling community attitudes toward the mentally ill. Schizophrenia Bulletin, 7 (2), 225-240. https://doi.org/10.1093/ schbul/7.2.225.

63. Thornicroft G., Mehta N., Clement S., Evans-Lacko S., Doherty M., Rose D., et al. (2016). Evidence for effective interventions to reduce mental health-related stigma and discrimination. Lancet. 387 (10023), 1123-1132. https://doi. org/10.1016/S0140-6736(15)00298-6.

64. Thornicroft G., Rose D., Kassam A. \& Sartorius N. (2007). Stigma: Ignorance, prejudice or discrimination? Br J Psychiatry, 190 (3), 192-193. https://doi. org/10.1192/bjp.bp.106.025791.

65. US National Institutes of Health (2007). Biological sciences curriculum study. Preuzeto s: https://www.ncbi.nlm.nih.gov/books/NBK20369/ (1.6.2020.)

66. Vranko, M. (2019). Primjena koncepta otpornosti u kontekstu posvojenja. U: Kokorić, S. B. (ur.), Posvojenje - različite perspektive, isti cilj. Zagreb: Na drugi način, 160-177.

67. Vučić Peitl, M., Tibljaš, D., Prološčić, J. \& Habibović, F. (2018). Stigmatizacija duševnih bolesnika od srednjoškolaca - Preuređeni dio istraživanja diplomskog rada Diplomskog sveučilišnog studija sestrinstvo - Promicanje i zaštita mentalnog zdravlja. Socijalna psihijatrija, 46 (3), 307-325.

68. Vukušić Rukavina, T. (2011). Razvoj mjernog instrumenta za procjenu stigmatizacije duševnih smetnji u tiskanim medijima. Doktorska disertacija. Zagreb: Sveučilište u Zagrebu, Medicinski fakultet.

69. Wahl, O. E., Wood, A. \& Richards R. (2002). Newspaper coverage of mental illness: Is it changing? Psychiatric Rehabilitation Skills, 6 (1), 9-31. https://doi. org/10.1080/10973430208408417.

70. Winkler, P., Mladá, K., Janoušková, M., Weissová, A., Tušková, E., Csémy, L. \& Evans-Lacko, S. (2016). Attitudes towards the people with mental illness: Comparison between Czech medical doctors and general population. Social Psychiatry and Psychiatric Epidemiology, 51 (9), 1265-1273. https://doi.org/10.1007/ s00127-016-1263-y.

71. Wolska, A., \& Malina, A. (2020). Personality and attitudes towards people with mental disorders: Preliminary studies results. International Journal of Social Psychiatry, 1-9. https://doi.org/10.1177/0020764020906433.

72. World Health Organization (2001a). The World Health Report 2001. Mental health: New understanding, new hope. Geneva: World Health Organization. 
73. World Health Organization (2001b). Mental Health Policy Project - Policy and service guidance. Geneva: World Health Organization.

74. WHO (2001c). Strengthening mental health promotion. Geneva, World Health Organization (Fact sheet, No. 220).

75. World Health Organization (2004). Mental health policy, plans and programmes - Rev. ed. Mental health policy and service guidance package. Geneva: World Health Organisation.

76. World Health Organization (WHO) (2005). Mental health declaration for Europe: Facing the challenges, building solutions. Copenhagen: World Health Organization.

77. World Health Organization (WHO) (2013a). Mental Health Action Plan 20132020. Geneva: WHO.

78. World Health Organization (WHO) (2013b). The Helsinki statement on health in all policies. Geneva: WHO.

79. Zavod za javno zdravstvo Federacije BiH (2012). Izvještaj istraživanja za Federaciju BiH. Sarajevo. Preuzeto s: http://www.zzjzfbih.ba/wp-content/uploads/2009/02/ Istrazivanje-stavova-javnosti-o-osobama-sa-mentalnim-poremecajima-u-FBiH. pdf (20.5.2020.)

80. Žiropađa, Lj. \& Dulović, A. (2014). Stavovi prema mentalno obolelim u Crnoj Gori: Adaptacija CAMI skale. Engram, 36 (3-4), 27-38. 
Ana Petak

Sveučilište u Zagrebu

Fakultet hrvatskih studija

Sanja Narić

Neuropsihijatrijska bolnica Dr. Ivan Barbot

Roberta Matković

Nastavni zavod za javno zdravstvo

Služba za mentalno zdravlje

\section{ATTITUDES TOWARD PEOPLE WITH MENTAL HEALTH DIFFICULTIES}

\section{ABSTRACT}

The implementation of modern approaches that seek to deinstitutionalize traditional psychiatric services is hampered by unfavorable attitudes of the community towards people with mental disabilities. Stigma is one of the most important factors that delay seeking help and negatively affects the quality of life of people with mental health problems. The research was conducted to describe attitudes towards people with mental health problems and determine their relationship with socio-demographic variables, information, and personal experience with mental health problems. There were 108 participants aged 21 to 59 (71\% female, 64.5\% college and university degrees). The Community Attitudes toward Mental IIIness scale (CAMI) (Taylor \& Dear, 1981) and a survey questionnaire were used online. Participants have generally benevolent attitudes toward all dimensions of the scale. Higher self-assessment of knowledge about mental health problems leads to more favorable attitudes towards authoritarianism, and younger age to less social restraint. Participants with a high school diploma have more negative attitudes towards the dimensions of authoritarianism and benevolence than participants with a university degree. There are no significant differences in attitudes regarding the experience of seeking mental health support, but on the authoritarian dimension, there is a significant interaction effect of being informed and mental health support seeking. The results indicate the importance of further research into the relationship between attitudes and mental health support seeking and the level of being informed on mental health issues.

Key words: mental health; mental health difficulties; attitudes; stigmatization

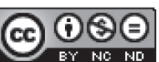

Međunarodna licenca / International License:

Creative Commons Attribution-NonCommercial-NoDerivatives 4.0. 
